\title{
Sub-lethal assessment of aqueous dried leaf extract of catharanthus roseus (linn.) g. don in male albino
}

\section{rats}

\begin{abstract}
Catharanthus roseus (Linn.) G. Don is one of the famous plants used in folk medicine for the treatment and management of many forms of diseases and infections. The ubiquitous nature of this plant sprang up the interest to ascertain the sub-lethal toxicity of aqueous dried leaf extract of the plant in male albino rats. Thirty two (32) male albino rats were used in the study and were broadly divided into two: twelve (12) rats were used for acute toxicity study while the remaining twenty (20) rats for sub-acute toxicity study. Median lethal dose $\left(\mathrm{LD}_{50}\right)$, body weight, relative organ weight, haematological indexes and liver function enzymes were all determined after fourteen (14) days oral administration of the plant extract using standard analytical methods. This research disclosed that there was no mortality throughout the period of both studies even after the administration of the highest dose $(10,000 \mathrm{mg} / \mathrm{kg}$ body weight $)$ of the extract. Similarly, it was observed that most of the examined indexes revealed dose dependent variations and there were no significant differences when compared to the control animals at $(\mathrm{p}<0.05)$ level of significance. Furthermore, the effects of the extract in the activities of hepatocellular enzymes (ALT, AST and ALP) and haematological indexes (MCV, WBC and Platelets) were found to be concentration dependent. This suggests that the administration of the aqueous extract of C. roseus could trigger off hepatocellular damage and haematological disorder if taken in large doses.
\end{abstract}

Keywords: catharanthus roseus, aqueous leaf extract, lethal dose, haematologic indexes, hepatocellular enzymes
Volume 3 Issue 5 - 2017

\author{
Ukoha AI,' Okereke SC,' Arunsi UO,' \\ Nwogu AC, ${ }^{2}$ Jack AB,' Chukwudoruo SC,' \\ Nnonyelum CE,' Bello HA3 \\ 'Department of Biochemistry, Abia State University, Nigeria \\ ${ }^{2}$ Department of Microbiology and Immunology, Abia State \\ University, Nigeria \\ ${ }^{3}$ Department of Biochemistry, Usmanu Danfodiyo University, \\ Nigeria
}

Correspondence: Arunsi UO, Department of Biochemistry, Faculty of Biological and Physical Sciences, Abia State University, Uturu,Abia, Nigeria, Email vennniabia@gmail.com

Received: September 25, 2017| Published: October 20, 2017
Abbreviations: $\mathrm{RBC}$, red blood cells; PCV, packed cell volume; $\mathrm{MCV}$, mean corpuscular volume; $\mathrm{MCHC}$, mean cell hemoglobin concentration; $\mathrm{MCH}$, mean corpuscular haemoglobin; $\mathrm{HB}$, hemoglobin; WBC, white blood cells

\section{Introduction}

The complete dependence on orthodox medicine by mankind to balance the biological doshas is significantly loosing firm grip by the day, and this has been observed over the years to be as a result of population size, inadequate supply of orthodox drugs, prohibitive treatment and toxic effects of several synthetic drugs. ${ }^{1}$ The introduction of herbal medicine to bridge this established therapeutic gap has renewed man's hope for survival and longevity. Medicinal plant; an essential ingredient of herbal medicine, is any plant or group of plants which confers good health benefits to man when religiously used. These plants have remained man's friend; thus providing food, medicine and shelter. ${ }^{2}$ The essentiality of plants and its products as panacea to ailments is not unconnected with the following benchmarks: bioaccumulation of phytoconstituents otherwise known as Phytochemicals, safety margin, less toxic, affordability, more compatible with the human body, reduced side effects and ability to target biochemical pathways. ${ }^{3-6}$ This is in consonance with the observation of the World Health Organization that about $80 \%$ of the world's population depends on medicinal plants to treat and manage infections and diseases; and in Africa, this rate is much higher.

One of such plants used in the world today for relieving ailments is Catharanthus roseus (Linn.) G. Don. 1838 Catharanthus roseus, an ornamental plant of the family Apocynaceae and order Gentianales, was previously referred to as Vinca rosea and commonly called Madagascar periwinkle. ${ }^{8}$ The leaves are oval to oblong in shape, $2.5-9.0 \mathrm{~cm}$ long and $1.0-3.5 \mathrm{~cm}$ broad, glossy green, hairless, with a pale midrib and a short petiole of about $1.0-1.8 \mathrm{~cm}$ long and they are arranged in opposite pairs. The flowers looks white to dark pink, with a darker red centre and a basal tube of $2.5-3.0 \mathrm{~cm}$ long with a corolla of about $2.0-5.0 \mathrm{~cm}$ diameter with five petals like lobes. The fruits are found to be a pair of follicles of about $2.0-4.0 \mathrm{~cm}$ long and $3 \mathrm{~mm}$ broad. ${ }^{9}$ C. roseus extracts has been used as a herbal medicine in India, Malaysia and China for the treatment of malaria, diabetes, insomnia, leukemia, Hodgkin's lymphoma and cancer due to the presence of active compounds in the plants. ${ }^{10}$ A pile of information on the ethno pharmaceutical relevance of the plant has been recently added in the pharmacopoeia, attributing the following biological activities to the leaf extracts of C. roseus: antihypertensive; hepatoprotective; antioxidant, antifungal, hypolipidemic, antibacterial, antidiabetic anticancer. ${ }^{11-13}$ Unfortunately, extreme toxicity was observed when humans consumed extracts of the plants orally and therefore, its cultivation, possession or sale was outlawed in the state of Louisiana. However the use of the plant was strictly for aesthetic, landscaping or decorating purposes but never for medicinal purposes. ${ }^{14}$ It is against this background that the present study was developed. Therefore, the thrust of this study was to evaluate the sub-lethal assessment of aqueous dried leaf extract of Catharanthus roseus (Linn.) G. Don in male albino rats by quantifying their hematological and hepatic enzyme indexes. 


\section{Materials and methods}

\section{Collection and identification of the plant}

The leaves of Catharanthus roseus (Figure 1) were harvested fresh from the courtyard of the Faculty of Biological and Physical Sciences and identified at the Department of Plant Science and Biotechnology, Abia State University, Uturu, Nigeria.

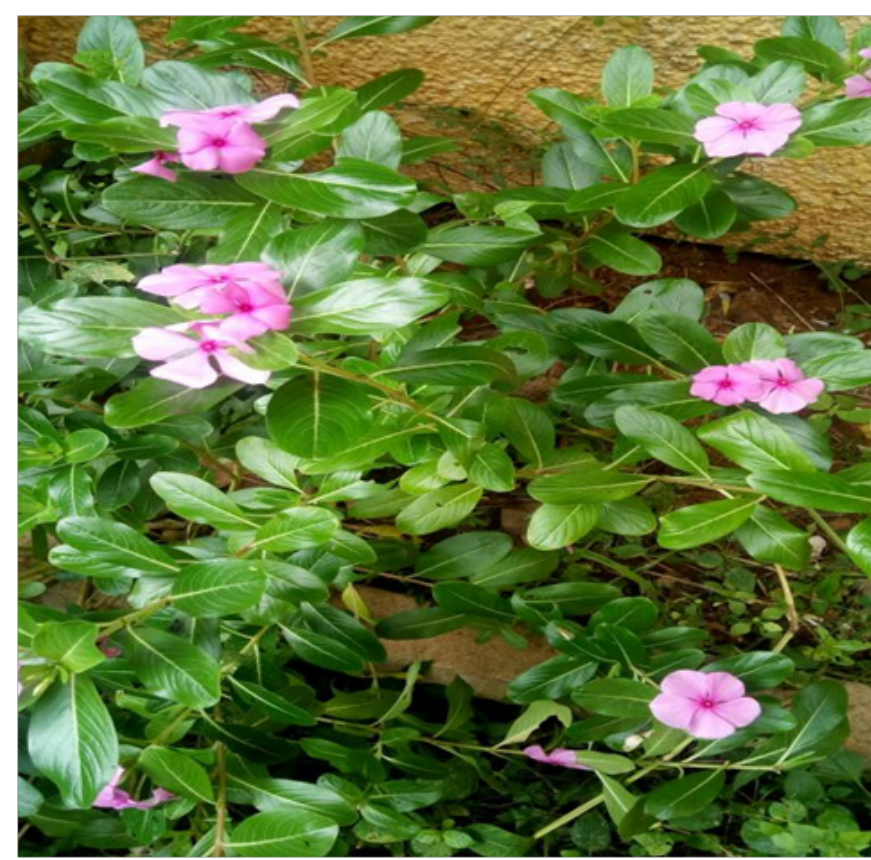

Figure I Pictorial representation of Catharanthus roseus (Linn.) G. Don.

\section{Preparation and processing of plant extract}

The leaves of Catharanthus roseus were properly sorted to remove dust and decayed materials, washed with distilled water and airdried for seven (7) days. After drying, the leaves were ground into fine powder using a mechanical homogenizer. The fine powder was poured into a clean dry container and was stored at room temperature before used for the analyses. Exactly $80 \mathrm{~g}$ of Catharanthus roseus dried leaves was soaked in aqueous medium of $750 \mathrm{ml}$ and allowed to stand for 24hours. It was filtered using a clean sieve. The filtrate was concentrated using rotary evaporator, and the extract stored in the refrigerator prior to use.

\section{Laboratory animals and experimental design}

Exactly Thirty two (32) weaned male albino rats, weighing 85 $105 \mathrm{~g}$ were obtained from the Department of Pharmacology and Toxicology, University of Nigeria, Nsukka, and were allowed to acclimatize for two (2) weeks in the Animal House of the Department of Biochemistry, Abia State University, Uturu. These animals were fed on grower's mash. All the animals used had free access to clean water. They were kept in well ventilated rooms with $12 / 12 \mathrm{~h}$ light/ dark condition and ambient room temperature. The experimental procedures used in this study conform to the United States National Institutes of Health Guidelines for Care and Use of Laboratory Animals in Biomedical Research ${ }^{15}$ and are grouped as shown below Table 1.
Table I Experimental design for acute and sub-lethal studies

\begin{tabular}{ll}
\hline A.Acute Toxicity & \\
\hline Groups (n=3) & $\begin{array}{l}\text { Extract Administration } \\
\text { (mg/kg Body Weight) }\end{array}$ \\
\hline A (Control) & $0.25 \mathrm{ml}$ of Distilled Water \\
B & 2000 \\
C & 5000 \\
D & 10000 \\
\hline B. Sub-Acute & \\
Toxicity & Extract Administration (mg/kg \\
\hline Groups (n=5) & Body Weight) \\
\hline I (Control) & $0.25 \mathrm{ml}$ of Distilled Water \\
II & 250 \\
III & 500 \\
IV & 1000 \\
\hline
\end{tabular}

\section{Lethal dose (LD50) study}

A standard method was adopted for the determination of median lethal dose $\left(\mathrm{LD}_{50}\right)$ of extract. ${ }^{16}$ The aqueous dried leaf extract of $C$. roseus was given to various groups (Table 1A). The animals were then observed for behavioral changes and mortality for 24 hours.

\section{Sub-lethal study}

Animals set for sub-acute toxicity study were orally administered with the respective concentrations of the aqueous dried leaf extract of C. roseus (Table 1B) for fourteen (14) days. They were fasted overnight, anaesthetized with chloroform and sacrificed on the fifteenth day.

\section{Blood collection}

Blood was collected by cardiac puncture using syringe and needle into plain and Ethylene diamine tetra-acetic acid (EDTA) bottles for liver function and haematological analyses respectively. The bottles were allowed to stand for 15 minutes, spun at 12,000rpm for 5 minutes using the centrifuge and serum and plasma were decanted respectively using a Pasteur pipette into another set of plain test tubes, covered and stored in a refrigerator prior to further analysis.

\section{Procedure for haematological parameters}

Standard operating procedures as described by Afia and Momoh ${ }^{17}$ using the BC-3200 Auto-Haematology Analyzer was used for estimation of the haematological parameters. Namely: white blood cells (WBC), neutrophils, eosinophilic, basophil, lymphocyte, monocyte, red blood cells (RBC), packed cell volume (PCV), mean corpuscular volume $(\mathrm{MCV})$, mean cell hemoglobin concentration (MCHC), Mean Corpuscular Haemoglobin (MCH), hemoglobin (Hb) and platelet were then calculated.

\section{Procedures for serum chemistry analysis}

The liver function enzymes; Alanine aminotransferase (ALT), aspartate aminotransferase (AST), and alkaline phosphatase (ALP) were spectrophotometrically determined using standard for the kits of Randox Laboratory Ltd, Co. Antrim, United Kingdom. 


\section{Statistical analysis}

Results were expressed as mean $\pm \mathrm{SD}$ (standard deviation). Statistical analysis was performed by One-way analysis of variance (ANOVA) with the Graph Path Prism ${ }^{\circledR}$ Statistic software package, version 7.01. One-way ANOVA with a Tukey's multiple comparisons test was used to identify statistical differences among groups. A $p$-value of $\leq 0.05$ was considered statistically significant.

\section{Results}

Table 2 showed the acute (oral) toxicity studies of aqueous dried leaf extract of Catharanthus roseus on male albino rats post 24 hours administration. From the result obtained, none of the twelve (12) rats died during the experimental time and therefore the median lethal $\left(\mathrm{LD}_{50}\right)$ of the aqueous dried leaf extract of Catharanthus roseus in albino rats was estimated to be greater than $10,000 \mathrm{mg} / \mathrm{kg}$ per body weight. The rats fed with $5000 \mathrm{mg} / \mathrm{kg}$ body weight of the extract were found to be dull and calm for the first four (4) hours but later normalized. Table 3 showed the effect of aqueous dried leaf extract of Catharanthus roseus on the body weight of male albino rats post 14days of administration. The result revealed that there was improvement in the percentage weight of the experimental animals when compared prior and post administration of the aqueous dried leaf extract. The percentage weight gain for control and the highest dose of the extract are 26.33 and $6.82 \%$ respectively. Table 4 showed the effects of aqueous dried leaf extract of Catharanthus roseus on the relative organ weight of male albino rats. The result revealed that there is no significant difference $(\mathrm{p}<0.05)$ in relative organ weight of the animals between the control and the test groups. The organ weight was not altered in all groups treated with various concentrations, ranging from 250,500 , and $1000 \mathrm{mg} / \mathrm{kg}$ body weight when compared with the control group. Table 5 showed the effect of aqueous dried leaf extract of Catharanthus roseus on serum concentrations of Alanine aminotransferase (ALT), Aspartate aminotransferase (AST) and Alkaline phosphatase (ALP) of male albino rats. The result revealed that there was an increase in the serum concentration of Alanine aminotransferase (ALT) however, this increase was not statistically significant at $(\mathrm{p}<0.05)$. The result further showed that the concentration of Aspartate aminotransferase (AST) and Alkaline phosphatase (ALP) increased significantly $(\mathrm{p}<0.05)$ between the control and test groups $(250,500$ and $1000 \mathrm{mg} / \mathrm{kg}$ body weight doses of the extract).

Table 2 Acute (oral) toxicity studies of albino rats after $24 \mathrm{hrs}$ of administration of aqueous dried leaf extract of Catharanthus roseus

\begin{tabular}{llll}
\hline Group & Dose $(\mathbf{m g} / \mathbf{k g})$ & D/T & $\begin{array}{l}\text { Sign of } \\
\text { toxicity }\end{array}$ \\
\hline A & $0.25 \mathrm{ml}\left(\mathrm{H}_{2} \mathrm{O}\right)$ & $0 / 3$ & No toxic effects observed \\
A & 2000 & $0 / 3$ & No toxic effect observed \\
B & 5000 & $0 / 3$ & $\begin{array}{l}\text { Dullness was observed within } \\
5 \text { minutes }\end{array}$ \\
C & 10000 & $0 / 3$ & Dullness and calmness \\
\hline
\end{tabular}

Table 6 showed the effect of aqueous dried leaf extract of Catharanthus roseus on haematological indexes (Packed Cell Volume, Haemoglobin; Red Blood Cells, Mean Corpuscular Volume, Mean Corpuscular Haemoglobin; Mean Corpuscular Haemoglobin Concentration; White Blood Cell [total and differential] and platelets) of male albino rats. There was a significant decrease $(p>0.05)$ in concentrations of platelets between the control and the test groups.
All other parameters assayed (Packed Cell Volume, Haemoglobin; Red Blood Cells, Mean Corpuscular Volume, Mean Corpuscular Haemoglobin; Mean Corpuscular Haemoglobin Concentration; White Blood Cell, Neutrophil, Eosinophilic, Basophil, Lymphocyte and Monocytes) showed dose dependent variation, but the change was not statistically significant at $\mathrm{p}<0.05$.

\section{Discussion}

The world today depends largely on products derived from plants to manage diseases and infections. Catharanthus roseus (Linn.) G. Don is one of such plants that have been exploited over the years to remedy ailments. It is against this background that the present study was developed to determine the sub-lethal assessment of aqueous dried leaf extract of Catharanthus roseus (Linn.) G. Don in male albino rats. The result of the acute $\left(\mathrm{LD}_{50}\right)$ toxicity studies of the aqueous dried leaf extract of Catharanthus roseus showed no mortality at the maximum dose of $10,000 \mathrm{mg} / \mathrm{kg}$ body weight (Table 2). Therefore, the median lethal dose estimated to be more than $10,000 \mathrm{mg} / \mathrm{kg}$ body weight in the albino rats is regarded as in safe category of drugs. ${ }^{18}$ Previous studies showed that $5000 \mathrm{mg} / \mathrm{kg}$ body weight of aqueous leaf extract of $C$. roseus orally administered to male albino rats did not cause adverse effects to the experimental animals. ${ }^{19}$ The result revealed that there was significant decrease in the percentage weight gain of the experimental animals between the control and the test groups. The degree in percentage weight gain is in the order $1000 \mathrm{mg} /$ $\mathrm{kg}<500 \mathrm{mg} / \mathrm{kg}<250 \mathrm{mg} / \mathrm{kg}<\mathrm{Control}$ (Table 3). The alteration in weight gain implies narrow safety margin and hence, the aqueous dried leaf extract of the plant should be used cautiously. It was suggested that the tested doses could have interfered with normal metabolism consequently affecting the uptake of food. ${ }^{19,20}$ The relative weight of organs (liver, spleen, kidneys, lungs, and heart) was not altered in all the groups treated with aqueous dried leaf extract of $C$. roseus when compared to the control group (Table 4). This implies that the plant extract at 14 days of exposure did not impact negatively on the relative organ weights. It has been reported that some herbal mixtures have hepatotoxic effects. ${ }^{21,22}$ The loss of integrity and functionality of this homeostatic organ (liver) would certainly lead to the increase in hepatocellular indexes: Alanine transaminase (ALP), Aspartate aminotransferase (AST) and Alkaline Phosphatase (ALP). ALT and AST are cytoplasmic enzymes found in very low concentrations in the liver and are released into the plasma following hepatocellular injury while ALP is a membrane bound enzyme that is released in the serum following pathological phenomena. ${ }^{23}$ The increase in the serum concentrations of these enzymes as observed in this study (Table 5) suggests the hepatotoxic effects of the aqueous dried leaf extract of $C$. roseus. These findings are in line with previous works of James et al., ${ }^{23}$ and Kabubii et al., ${ }^{19}$ who reported that the ingestion of the aqueous leaf extracts of the plant resulted in the elevation of ALT, AST and ALP at different doses of $1.0 \mathrm{~g} / \mathrm{kg}$ and $5.0 \mathrm{~g} / \mathrm{kg}$ body weight in New Zealand breed of rabbits, Sprague Dawley female rats and albino rats respectively. ${ }^{19,20,23}$ Similar observation was made by Upmanya et al., ${ }^{24}$ who tested the intravenous administration of $1.0 \mathrm{mg} /$ $\mathrm{kg}$ of $C$. roseus alkaloid Vincristine and found a significant increase in liver enzymes. ${ }^{24}$ Therefore, this study suggested that the aqueous dried leaf extract of the plant could only be hepato-friendly if taken at lower doses.

The results of this study also demonstrated a marked level in haematological parameters within the references range. It has been shown that certain conventional drugs or chemicals adversely affect 
the various blood components. Haematotoxicity sets in when there is elevation of these blood components beyond their reference ranges. ${ }^{25}$ The effect of $C$. roseus on some haematological index is indicated in $\mathrm{MCV}, \mathrm{WBC}$ and platelets. MCV is the measure of the size of the red blood cells. Smaller MCV indicates that RBCs will be smaller than normal and this is described as microcystic; elevated MCV indicates that RBCs will be larger than normal and is termed macrocystic; whereas RBCs of normal size are termed normocystic. ${ }^{26}$ These size categories are relied upon in the classification of anaemia types. In this study, the toxic effect was significant only at the highest dose of $1000 \mathrm{mg} / \mathrm{kg}$. This observation was in agreement with the findings of Kabubii et al., ${ }^{19}$ who reported a significant decrease in blood concentration of platelets. ${ }^{19}$ The significant decrease in the blood level of platelets implied that long term exposure to aqueous dried leaf extract of $C$. roseus could be dangerous to health. However, the findings suggested that the aqueous dried leaf extract of the plant may have no adverse effect on the bone marrow (the chief organ for haematopoietic processes and susceptible targets of toxic compounds) and the liver (the central hub of metabolism) if cautiously used (that is at low doses).

Table 3 Effects of aqueous dried leaf extract of Catharanthus roseus on the body weight of albino rats after 14 days of administration

\begin{tabular}{|c|c|c|c|c|}
\hline Number of days & Control & Group I (250mg/kg) & Group II (500mg/kg) & Group III (1000mg/kg) \\
\hline 0 & $83.00 \pm 5.57$ & $102.20 \pm 12.76$ & $89.20 \pm 11.30$ & $98.40 \pm 12.20$ \\
\hline 14 & $\mid \mathrm{I} 2.67 \pm 12.50$ & $124.80 \pm 9.76$ & $103.40 \pm 12.64$ & $105.60 \pm 9.15$ \\
\hline Weight gain (g) & 29.67 & 22.6 & 14.2 & 7.2 \\
\hline Weight gain (\%) & 26.33 & 18.1 & 13.73 & 6.82 \\
\hline
\end{tabular}

Values represent the mean $\pm S D$ for $N=5$.

Table 4 Effects of aqueous dried leaf extracts of Catharanthus roseus on the relative organ weight of albino rats

\begin{tabular}{|c|c|c|c|c|}
\hline Organ & Control & Group I (250mg/kg) & Group II (500mg/kg) & Group III (1000mg/kg) \\
\hline Liver & $4.93 \pm 0.25^{a}$ & $4.62 \pm 1.20^{\mathrm{a}}$ & $5.62 \pm 0.65^{\mathrm{a}}$ & $4.62 \pm 0.69^{a}$ \\
\hline Spleen & $0.72 \pm 0.04^{a}$ & $0.75 \pm 0.29^{a}$ & $0.99 \pm 0.11^{\mathrm{a}}$ & $0.73 \pm 0.20^{\mathrm{a}}$ \\
\hline Kidneys & $0.92 \pm 0.05^{\mathrm{a}}$ & $0.88 \pm 0.11^{a}$ & $0.99 \pm 0.17^{\mathrm{a}}$ & $0.84 \pm 0.05^{\mathrm{a}}$ \\
\hline Lungs & $0.97 \pm 0.29^{a}$ & $\mathrm{I} .0 \mathrm{I} \pm 0.3 \mathrm{I}^{\mathrm{a}}$ & $0.99 \pm 0.25^{\mathrm{a}}$ & $0.82 \pm 0.18^{\mathrm{a}}$ \\
\hline Heart & $0.41 \pm 0.03^{a}$ & $0.44 \pm 0.05^{a}$ & $0.49 \pm 0.12^{\mathrm{a}}$ & $0.43 \pm 0.05^{a}$ \\
\hline
\end{tabular}

Table 5 Effect of aqueous dried leaf extract of Catharanthus roseus on hepatic enzymes of albino rats

\begin{tabular}{lllll}
\hline Parameter & Control & Group I (250mg/kg) & Group II (500 $\mathbf{m g} / \mathbf{k g})$ & Group III ( I 000 $\mathbf{m g} / \mathbf{k g})$ \\
\hline ALT (U/L) & $32.33 \pm 6.03^{\mathrm{a}}$ & $36.67 \pm 4.16^{\mathrm{a}}$ & $35.67 \pm 3.5 \mathrm{I}^{\mathrm{a}}$ & $37.67 \pm 0.58^{\mathrm{a}}$ \\
AST (U/L) & $30.33 \pm 1.53^{\mathrm{a}}$ & $33.33 \pm 1.53^{\mathrm{a}}$ & $38.00 \pm 1.00^{\mathrm{b}}$ & $39.67 \pm 3.2 \mathrm{I}^{\mathrm{c}}$ \\
ALP (U/L) & $85.59 \pm 2.92^{\mathrm{a}}$ & $87.97 \pm 2.56^{\mathrm{a}}$ & $90.76 \pm 4.37^{\mathrm{b}}$ & $92.18 \pm 9.85^{\mathrm{c}}$
\end{tabular}

Values represent the mean $\pm S D$ for $N=5$.Values in the same rows bearing the same letter of the alphabet are not significantly different from each other ( $>0.05$ ). Alanine aminotransferase (ALT), Aspartate aminotransaferase (AST) and Alkaline phosphatase (ALP).

Table 6 Effect of aqueous dried leaf extract of Catharanthus roseus on haematological indexes of albino rats

\begin{tabular}{|c|c|c|c|c|}
\hline Indexes & Control & Group I (250mg/kg) & Group II (500mg/kg) & Group III(I000mg/kg) \\
\hline $\mathrm{PCV}(\%)$ & $51.70 \pm 6.84^{\mathrm{a}}$ & $50.93 \pm 1.78^{\mathrm{a}}$ & $50.43 \pm 4.05^{\mathrm{a}}$ & $49.80 \pm 3.90^{\mathrm{a}}$ \\
\hline $\mathrm{Hb}(\mathrm{g} / \mathrm{dl})$ & $12.67 \pm 0.76^{\mathrm{a}}$ & $12.43 \pm 1.25^{\mathrm{a}}$ & $12.93 \pm 0.6 \mathrm{I}^{\mathrm{a}}$ & $12.91 \pm 0.79^{a}$ \\
\hline $\mathrm{RBC}\left(\times 10^{12} / \mathrm{L}\right)$ & $6.26 \pm 0.95^{a}$ & $6.76 \pm 1.2 \mathrm{I}^{\mathrm{a}}$ & $7.47 \pm 0.52^{\mathrm{a}}$ & $7.56 \pm 1.10^{\mathrm{a}}$ \\
\hline MCV (fl) & $82.94 \pm 5.83^{a}$ & $76.89 \pm 12.49^{a}$ & $67.50 \pm 1.86^{\mathrm{a}}$ & $66.66 \pm 1.70^{\mathrm{a}}$ \\
\hline $\mathrm{MCH}(\mathrm{pg})$ & $20.39 \pm 2.1 I^{a}$ & $18.55 \pm 1.60^{a}$ & $17.29 \pm 0.56^{\mathrm{a}}$ & $16.50 \pm 0.6 \mathrm{I}^{\mathrm{a}}$ \\
\hline $\mathrm{MCHC}(\mathrm{g} / \mathrm{L})$ & $244.67 \pm 21.13^{a}$ & $243.33 \pm 16.74^{a}$ & $256.33 \pm 8.02^{\mathrm{a}}$ & $249.33 \pm 12.0 \mathrm{I}^{\mathrm{a}}$ \\
\hline WBC (xI09/L) & $7.40 \pm 0.78^{a}$ & $8.49 \pm 3.67^{a}$ & $6.87 \pm 3.18^{a}$ & $6.95 \pm 0.36^{a}$ \\
\hline
\end{tabular}




\begin{tabular}{|c|c|c|c|c|}
\hline Indexes & Control & Group I (250mg/kg) & Group II (500mg/kg) & Group III(1000mg/kg) \\
\hline Neutrophil (\%) & $51.67 \pm 1.53^{\mathrm{a}}$ & $51.67 \pm 2.52^{\mathrm{a}}$ & $51.33 \pm 1.15^{\mathrm{a}}$ & $54.67 \pm 1.53^{b}$ \\
\hline Lymphocyte (\%) & $43.00 \pm 1.00^{\mathrm{a}}$ & $41.33 \pm 2.52^{\mathrm{a}}$ & $45.00 \pm 1.00^{\mathrm{a}}$ & $41.00 \pm 1.00^{\mathrm{a}}$ \\
\hline Eosinophil (\%) & $1.00 \pm 0.00^{\mathrm{a}}$ & $1.67 \pm 0.58^{\mathrm{a}}$ & $0.67 \pm 0.58^{a}$ & $1.00 \pm 0.00^{\mathrm{a}}$ \\
\hline Basophil (\%) & $0.33 \pm 0.58^{a}$ & $1.00 \pm 0.00^{\mathrm{a}}$ & $0.67 \pm 0.58^{a}$ & $0.67 \pm 0.58^{\mathrm{a}}$ \\
\hline Monocytes (\%) & $4.00 \pm 1.00^{\mathrm{a}}$ & $4.33 \pm 0.58^{\mathrm{a}}$ & $2.33 \pm 0.58^{\mathrm{a}}$ & $2.67 \pm 0.58^{\mathrm{a}}$ \\
\hline Platelets $\left(\times 10^{9} / \mathrm{L}\right)$ & $680.00 \pm 110.24^{\mathrm{a}}$ & $624.00 \pm 168.01^{b}$ & $638.00 \pm 158.7 I^{b}$ & $536.33 \pm 72.97^{c}$ \\
\hline
\end{tabular}

\section{Conclusion}

The results of the present study showed that the oral administration of aqueous dried leaf extract of Catharanthus roseus may lead to hepatocellular and haematological disorders when consumed in large doses, hence, rebutting its widespread applications in ethno medicine for the treatment and management of diseases. Consequently safety measures, have to be taken in the administration of the aqueous dried leaf extract of the plant.

\section{Acknowledgements}

The authors duly appreciate the Chief Laboratory Technologist of the Department of Biochemistry, Faculty of Biological and Physical Sciences, Abia State University, Uturu, Mr. Asomugha, C.O. for his technical inputs throughout the period of the research.

\section{Conflict of interest}

The author declares no conflict of interest.

\section{References}

1. Richton GM. Natural product as a robust source of new drugs and drug leads: past successes and present day issues. Am J Cardiol. 2008;101(10A):43-49.

2. Jaleel CA, Gopi R, Gomathinayam M, et al. Traditional and nontraditional plant growth regulators alters phytochemical constituents in Catharanthus roseus. Process Biochemistry. 2009;44(22):205-209.

3. Sofowora A. Medicinal Plant and Traditional Medicine in Africa. 3rd ed. Nigeria; 1993. p. 172-188.

4. Dutta S, Chatterjee MS, Chatterjee S. An overview on ethnophytopathological studies of Cassia alata- An important medicinal plants and the effect of VAM on its growth and productivity. International Journal of Research in Botany. 2012;2(4):13-19.

5. Ezekwesili CN, Ghasi S, Adindu CS, et al. Evaluation of the antiulcer property of aqueous extract of unripe Musa paradisiaca Linn. Peel in wistar rats. African Journal of Pharmacy and Pharmacology. 2014;8(39):1006-1011.

6. Okereke SC, Arunsi UO, Nosiri CI, et al. Gas chromatography mass spectrometry/Fourier transform infrared (GC-MS/FTIR) spectral analyses of Tithonia diversifolia (Hemsl.) A. Gray leaves. Journal of Medicinal Plants Research. 2017;11(19):345-350.

7. World Health Organization. Legal status of traditional medicine and complementary/alternative medicine: A world wide review. USA: WHO Publishing; 2001.

8. Gajalakshmi S, Vijayalakshmi S, Devi Rajeswari V. Pharmacological activities of Catharanthus roseus:a perspective review. International Journal of Pharma and Bio Sciences. 2013;4(2):431-439.
9. Sain M, Sharma V. Catharanthus roseus (An anti-cancerous drug yielding plant) - A Review of Potential Therapeutic Properties. International Journal of Pure \& Applied Bioscience. 2013;1(6):139142.

10. Wart C. Medicinal plant of Southeast Asia. Selangor: Prentice Hall; 2013. p. 224-225

11. Ara N, Rashid M, Amran S. Comparison of hypotensive and hypolipidemic effects of Catharanthus roseus leaves extract with atenolol on adrenaline induced hypertensive rats. Pak J Pharm Sci. 2009;22(3):267-271.

12. Balaabirami S, Patharajan S. In vitro antimicrobial and antifungal activity of Catharanthus roseus leaves extract against important pathogenic organisms. International Journal of Pharmaceutical Sciences. 2012;4(3):487-490.

13. Barkat A, Mujeeb M. The comparative study of Catharanthus roseus extract and extract loaded chitosan nanoparticles in alloxan induced diabetes rats. International Journal of Biological Research. 2013;4(12):670-678.

14. Shamsi S, Sultana R. Report on Phylloplane mycoflora associated with Catharanthus roseus (Linn.) G. Don- A herbal medicinal plant in Bangladesh. Bangladesh Journal of Science Resource. 2014;27(2):201207.

15. National Research Council. A guide for the care and use of laboratory animals. A report of the Institute of Laboratory Animal Research Committee on Care and Use of Laboratory Animals. Washington DC: National Institute of Health Publication, 1985, No. 85-123, National Academy Press.

16. Lorke D. A new approach to practical acute toxicity testing. Archives of Toxicology. 1983;54(4):275-287.

17. Afia ES, Momoh JA. Standard operating procedure. Nigeria: Unpublished guideline for the chemical pathology laboratory, National Hospital; 2006.

18. Organization for Economic Cooperation and Development (OECD). Environment, Health and Safety Publications Series on Testing and Assessment, No 24 guidance document on acute oral toxicity testing. 2000 .

19. Kabubii ZN, Mbaria JM, Mbaabu M. Acute toxicity studies of Catharanthus roseus aqueous extract in male Wistar rats. African Journal of Pharmacology and Therapeutics. 2015;4(4):130-134.

20. Kevin LYW, Hussin AH, Zhari I, et al. Sub-acute oral toxicity study of methanol leaves extract of Catharanthus roseus in rats. Journal of Acute Disease. 2012;1(1):38-41.

21. Lin TJ, Su CC, Lan CK, et al. Acute poisoning with Breynia officinalisan outbreak of hepatotoxicity. Journal of Toxicology and Clinical Toxicology. 2003;41(5):591-594. 
22. Shahraki MR, Arab MR, Marimo KE, et al. The effect of Teucrium polium (Calpoureh) on liver function, serum lipids and glucose in diabetic male rats. Iran Biomed J. 2007;11(1):65-68.

23. James A, Bilbiss L, Muhammad Y. The effects of Catharanthus roseus (L) G. Don 1838 aqueous leaf extract on some liver enzymes, serum proteins and vital organs. Science World Journal. 2007;2(1):5-7.

24. Upmanyu R, Dvivedi J, Saxena Y. Hepatotoxic effect of vincristine: an experimental study on albino rats. Indian J of Physiol and Pharmaco. 2009;53(3):265-270.
25. Dioka C, Orisakwe OE, Afonne OJ, et al. Investigation into the haematologic and hepatoxic effects of rinba-cin in rats. Journal of Health Science. 2002;48(5):393-398.

26. Chernecky C, Barbara C, Berger J. Laboratory tests and diagnostic procedures. 3rd ed. USA: WB Saunders Company; 2001. 